\title{
ПОШИРЕНІСТЬ ШТАМІВ Н.РУLОRI У ХВОРИХ НА ПЕПТИЧНУ ВИРАЗКУ ШЛУНКА ТА ДВАНАДЦЯТИПАЛОЇ КИШКИ У ПОЄДНАННІ 3 АРТЕРІАЛЬНОЮ ГІПЕРТЕНЗІЄЮ І ЦУКРОВИМ ДІАБЕТОМ ТИПУ 2
}

Вищий державний навчальний заклад України «Буковинський державний медичний університет», м. Чернівці

Резюме. У статті відображена поширеність токсигених штамів Helicobacter pylori (H.pylori) серед обстежених осіб. Обстежено 50 хворих (на хронічний гастрит, пептичну виразку шлунка та дванадцятипалої кишки у поєднанні з артеріальною гіпертензією і цукровим діабетом типу 2). Аналіз генетичних особливостей H.pylori показав широку неоднорідність його геному. Встановлено, що вірулентні штами H.pylori CagA VacA

Вступ. Важливе місце у структурі захворювань травної системи займають ерозивновиразкові Н.pylori-асоційовані ураження верхніх відділів травного каналу, а саме: хронічний гастрит (ХГ), пептична виразка шлунка (ПВШ) та дванадцятипалої кишки (ДПК), розвиток і перебіг яких залежить від цитотоксичності штамів H.pylori [1, 2] та наявності супутньої патології. Відомо, що CagA i VacA є одними з основних факторів порушення цілісності слизової оболонки (СО) епітелію шлунка, неконтрольованої проліферації епітеліальних та лімфоїдних клітин [5], вакуолізації клітин шлункового епітелію, порушення цитоскелетної архітектоніки [4] тощо. Однак поєднання вищезазначених штамів H.pylori та їх різні алельні комбінації призводять до підвищення секреції прозапальних цитокінів, апоптозу та зменшення стійкості епітеліальних клітин [1].

Мета роботи. Дослідити поширеність токсичних штамів Н.pylori у хворих на хронічний гастрит, пептичну виразку шлунка та дванадцятипалої кишки у поєднанні з артеріальною гіпертензією і цукровим діабетом типу 2.

Матеріал і методи. Обстежено 50 хворих (13 пацієнтів із ХГ (група 1), 12 - на ХГ із АГ і ЦД2 (група 2), 12 - на ПВШ та ДПК (група 3), 13 - на ПВШ та ДПК із АГ і ЦД2 (група 4)). Критеріями включення в дослідження є: ХГ H.pyloriасоційований, ПВШ та ДПК Н.pylori-асоційована; АГ I та II стадії, 1-го та 2-го ступеня; ЦД 2 легкої тяжкості, компенсований та середньої тяжкості, субкомпенсований. Критеріями виключення є: ускладнена ПВШ та ДПК, рак шлунка, симптоматична АГ, АГ ІІІ стадії, 3-го ступеня; ЦД 2 тяжкого ступеня, декомпенсований. Штами CagA, VacA H.pylori у біоптатах визначали за допомогою ПЛР наборів реагентів «Хелікопол» («Літех», Росія).

Результати дослідження та їх обговорення. При досліджені штамів Н.pylori виявлено, що у 1й і 2-й групах штами (CagA+VacA+) спостерігалися в трьох осіб $(23,08 \%)$ і в семи осіб $(58,33 \%)$ відповідно, (CagA+VacA-) - у двох осіб (15,37 \%) 1-ї групи і не виявлено у 2-й групі, (CagA-VacA+) - у семи осіб $(53,87 \%)$ і у чотирьох осіб (c) О.І. Федів, І.О. Сіцінська, І.С. Давиденко, 2016 172 та їх алельна комбінація (m1m2s1s2) призводить до розвитку деструктивних змін у слизовій оболонці шлунка та дванадцятипалої кишки, тяжкості запального процесу в слизовій оболонці і збільшує тривалість перебігу хронічної гастродуоденальної патології.

Ключові слова: H.pylori, CagA, VacA, пептична виразка шлунка, дванадцятипала кишка, артеріальна гіпертензія, цукровий діабет 2.

$(33,33 \%),(\mathrm{CagA}-\mathrm{VacA}-)$ - в однієї особи $(7,68 \%)$ та в однієї особи (8,3\%). Аналогічно, у 3-й та 4-й групах поширеність штамів (CagA+VacA+) спостерігається у восьми осіб $(66,66 \%)$ і в дев'яти осіб (69,23 \%), (CagA+VacA-) - не виявлено у 3-й групі та одна особа $(8,33$ \%) 4-ї групи, (CagA$\mathrm{VacA}+)$ - у трьох осіб $(25 \%)$ і у трьох осіб (20,07 \%), (CagA-VacA-) - у однієї особи $(8,33 \%)$ 3-ї групи і не виявлено у 4-й групі відповідно.

Отже, серед обстежених груп найвищий відсоток наявності штамів (CagA+VacA+) спостерігалися у групі хворих на ПВШ та ДПК із АГ і ЦД2. Штами (CagA+VacA-), (CagA-VacA+) частіше траплялися в 1-й групі пацєнтів, а (CagA-VacA-) у 1-й, 2-й, 3-й групах пацієнтів. Відомо, що наявність CagA i VacA $є$ додатковим фактором ризику розвитку ХГ, ПВШ та ДПК, раку шлунка (РШ) в осіб, інфікованих Н. pylori [2], а їх поєднання є маркером тяжкості захворювання [3].

Досліджуючи поширеність алелів (s1, m1, s2, m2) штаму VacA H.pylori y 1-й групі встановлено, що у хворих на ХГ трапляється алель $\mathrm{m} 1$ у семи осіб (58,86\%), m2 - у трьох осіб (20,07\%), s1 - у десяти осіб (76,92 \%), s2 - у дев'яти осіб (69,23\%). Однак поєднання алелів штаму трапляється в таких комбінаціях: m1m2s1s2 - у двох осіб (15,38 \%), m1s1 - в однієї особи $(7,69 \%)$, m1s1s2 - у чотирьох осіб (30,78 \%), m2s1s2 - в однієї особи (7,69\%), s1s2 - у двох осіб (15,38 \%). У групі хворих на ХГ із АГ і Ц2 спостерігалася наявність алелів $\mathrm{ml}$ у дев'яти осіб (75\%), m2 - у дев'яти осіб (75\%), s1 - у семи осіб $(58,33 \%)$, s2 - у восьми осіб $(66,67 \%)$ та трапляється поєднання алелів: m1m2s1s2 - у п'яти осіб (41,66 \%), m2s1s2 - в днієї особи (8,33 \%), m1m2s1 - в однієї особи $(8,33 \%), \mathrm{m} 1 \mathrm{~m} 2 \mathrm{~s} 2-$ у двох осіб $(16,67 \%)$.

Досліджуючи поширеність штамів VacA H.pylori у групі хворих на ПВШ та ДПК встановлена наявність таких алелів та їх комбінацій: алель $\mathrm{m} 1$ - у восьми осіб (66,66 \%), m2 - у дев'яти осіб (75\%), s1 - у шести осіб (50\%), s2 - у шести осіб (50\%) та їх поєднання: $\mathrm{m} 1 \mathrm{~m} 2 \mathrm{~s} 1 \mathrm{~s} 2-\mathrm{y}$ двох осіб (16,66 \%), m1m2s1 - у двох осіб $(16,66 \%), \mathrm{m} 1 \mathrm{~m} 2$ - в однієї особи $(8,33 \%), \mathrm{m} 2 \mathrm{~s} 2$ у двох осіб $(16,66 \%), \mathrm{m} 2 \mathrm{~s} 1$ - в однієї особи 
(8,33 \%). Водночас у групі хворих на ПВШ та ДПК із АГ і ЦД2 спостерігався наступний відсоток поширення алелів серед обстежених хворих: m1 - у 10 осіб (76,92\%), m2 - у 13 осіб (100\%), s1 - у шести осіб $(46,15 \%)$, s2 - у дев'яти осіб $(69,23 \%)$ та їх поєднання: $\mathrm{m} 1 \mathrm{~m} 2 \mathrm{~s} 1 \mathrm{~s} 2$ - у п'яти осіб $(38,46 \%), \mathrm{m} 1 \mathrm{~m} 2 \mathrm{~s} 2$ - в однієї особи $(7,69 \%)$, m1m2 - у трьох осіб (23,08\%), m2s2 - в однієї особи $(7,69 \%), \mathrm{m} 2 \mathrm{~s} 1 \mathrm{~s} 2$ - в однієї особи $(7,69 \%)$.

Відомо, що алельне поєднання s1m1 штаму VacA H.pylori має найвищий рівень цитотоксичної активності, що призводить до широкого клітинного тропізму s1m1 генотипів $[4,5]$ i $є$ причиною розвитку запально-деструктивних процесів та виразкових дефектів СО шлунка та ДПК і ускладнює перебіг за наявності супутньої патології.

\section{Висновок}

У хворих на хронічний гастрит виявлені часте поєднання штамів H.pylori CagA+VacA+ (23,08 \%), $\mathrm{CagA}-\mathrm{VacA}+(53,87 \%)$ та алельні комбінації: m1m2s1s2 (15,38\%), m1s1s2 (30,78\%), s1s2 (15,38\%); у хворих на пептичну виразку шлунка та дванадцятипалої кишки - CagA+VacA+ (66,66 \%), CagA-VacA+ (25\%) та їх алельні комбінації: $\mathrm{m} 1 \mathrm{~m} 2 \mathrm{~s} 1 \mathrm{~s} 2(16,66 \%)$, $\mathrm{m} 1 \mathrm{~m} 2 \mathrm{~s} 1(16,66 \%), \mathrm{m} 2 \mathrm{~s} 2(16,66 \%)$; у хворих на хронічний гастрит у поєднані з артеріальною гіпертензією і цукровим діабетом типу 2 - CagA+VacA $+(58,33 \%)$ $\mathrm{CagA}-\mathrm{VacA}+(33,33 \%)$ та іï алельна комбінація mlm2s1s2 (41,66 \%), m1m2s2 (16,67 \%); у хворих на пептичну виразку шлунка та дванадцятипалої кишки у поєднані 3 артеріальною гіпертензією і цукровим діабетом типу 2 - $\mathrm{CagA}+\mathrm{VacA}+(69,23 \%)$, CagA$\mathrm{VacA}+(20,07 \%)$ та їх алельних комбінацій m1m2s1s2 $(38,46 \%), \operatorname{mlm} 2(23,08 \%)$.

Перспективи подальших досліджень. Вiдомості про поширення штамів Н.pylori та їх алельні комбінації i оцінка стану судинноендотеліальної дисфункції, системи гемостазу та зміни епітелію $є$ основою діагностики 3 подальшим використаням ефективних схем лікування.

\section{Література}

1. Катеренчук І.П. Пептична виразка шлунка: особливості терапії, нерозв'язані проблеми, шляхи вирішення / І.П. Катеренчук // Внутр. мед. - 2007. - № 6 (66) [Электронный pecypc] // Режим доступа http:// www.mif-ua.com/archive/article/3072

2. Костюк О.В. Фактори патогенності Н.Р: генотипові основи та фенотипові прояви / О.В. Костюк // Профілакт. мед. - 2012. - № 2 (18). - С. 65-70.

3. Павлов О.Н. Связь инфекции Helicobacter pylori и системного воспаления у больных с нестабильным течением ишемической болезни сердца / О.Н. Павлов // Практ. мед. гастроэнтерол. - 2012. - № 3 [Электронный ресурс] // Режим доступа http:// pmarchive.ru

4. Зак М.Ю. Вплив токсигенних штамів Н. pylori на морфологічні зміни в слизовій оболонці шлунка у пацієнтів 3 хронічним атрофічним гастритом / М.Ю. Зак // Сучас. гастроентерол. - 2010. - № 5 (55). - С. 37-42.

5. Tegtmeyer N. Role of the cag-pathogenicity island encoded type IV secretion system in Helicobacter pylori pathogenesis / N. Tegtmeyer, S. Wessler, S. Backert // FEBS J. - 2011. - № 278. - P. 1190-1202.

\title{
РАСПРОСТРАНЕННОСТЬ ШТАММОВ Н. РУLОRІ У БОЛЬНЫХ С ПЕПТИЧЕСКОЙ ЯЗВОЙ ЖЕЛУДКА И ДВЕНАДЦАТИПЕРСТНОЙ КИШКИ В СОЧЕТАНИИ С АРТЕРИАЛЬНОЙ ГИПЕРТЕНЗИЕЙ И САХАРНЫМ ДИАБЕТОМ ТИПА 2
}

\author{
А.И. Федив, И.А. Сицинская, И.С. Давиденко
}

Резюме. В статье отражена распространенность токсигених штаммов Helicobacter pylori (H.pylori) среди обследованных лиц. Обследовано 50 больных (хроническим гастритом, пептической язвой желудка и двенадцатиперстной кишки в сочетании с артериальной гипертензией и сахарным диабетом типа 2). Анализ генетических особенностей H.pylori показал широкую неоднородность его генома. Установлено, что вирулентные штаммы Н.pylori СадА VacA и их аллельная комбинация $(\mathrm{m} 1 \mathrm{~m} 2 \mathrm{~s} 1 \mathrm{~s} 2)$ приводит к развитию деструктивных изменений в слизистой оболочке желудка и двенадцатиперстной кишки, тяжести воспалительного процесса в слизистой оболочке и увеличивает длительность течения хронической гастродуоденальной патологии.

Ключевые слова: H.pylori, CagA, VacA, пептическая язва желудка, двенадцатиперстная кишка, артериальная гипертензия, сахарный диабет 2 .

\section{THE PREVALENCE OF STRAINTS OF H. PYLORI IN PATIENTS WITH PEPTIC ULCER OF STOMACH AND DUODENAL ULCERS IN COMBINATION WITH ARTERIAL HYPERTENSION AND DIABETES 2}

\section{O.I. Fediv, I.O. Sitsinska, I.S. Davydenko}

Abstract. The article reflects the prevalence of toxigenic strains of Helicobacter pylori (H.pylori) among the surveyed persons. A total of 50 patients with (chronic gastritis, peptic ulcer and duodenal ulcer in combination with arterial hypertension and diabetes mellitus type 2) have been examined. Analysis of the genetic characteristics of H.pylori showed a wide heterogeneity of its genome. It is established that virulent strains of H.pylori CagA, VacA and combination $(\mathrm{m} 1 \mathrm{~m} 2 \mathrm{~s} 1 \mathrm{~s} 2)$ leads to the development of destructive changes in the mucous membrane of the stomach and duodenum, the severity of the inflammatory process in the mucosa and increases the duration of chronic gastroduodenal pathology.

Key words: H.pylori, CagA, VacA, peptic ulcer of the stomach, duodenum, arterial hypertension, diabetes 2.

Higher State Educational Institution of Ukraine "Bukovinian State Medical University” (Chernivtsi)

Рецензент - проф. О.І. Волошин
Buk. Med. Herald. - 2016. - Vol. 20, № 2 (78). - P. 172-173 